DOI : $10.24850 / \mathrm{j}-$ tyca-2021-04-09

Articles

\title{
Flood risk management contributions in localized areas. Case study: Tunja, Colombia
}

\section{Contribuciones a la gestión del riesgo de inundación en zonas localizadas. Caso de estudio: Tunja, Colombia}

Carlos Andrés Caro-Camargo1, ORCID: http://orcid.org/0000-00015568-1219

Laura Gil-Alvarado²

${ }^{1}$ Facultad de Ingeniería Civil, Universidad Santo Tomás, Tunja, Colombia, carlos.caroc@usantoto.edu.co

2Facultad de Ingeniería Civil, Universidad Santo Tomás, Tunja, Colombia, lau.yga@gmail.com

Corresponding author: Carlos Andrés Caro-Camargo, carlos.caroc@usantoto.edu.co,carlosandrescaro@gmail.com

\section{Abstract}

In an increasingly urbanized world, local governments have greater responsibility to implement practical measures against climate change. Measures that help prevent, mitigate, and efficiently overcome events 
such as floods, focusing on sustainable urban development. The present project is developed for the city of Tunja, Colombia. In this, sectors with high flood threat are evaluated, according to the main bodies of water that cross the urban area, Jordán River and La Vega River. The research purpose is to provide strategies that promote the correct flood risk management in the municipality. There are three priority topics, (1) importance of urban planning and management, (2) study of vulnerability from the social perception of the exposed inhabitants, and, finally, (3) a proposal of strategic alternatives according to the analyzed risk. It is aimed at the timely prevention promotion and affectations reduction, a product of precipitation events due to climatic variability.

Keywords: Floods, risk management, social perception, sustainable urban development, vulnerability.

\section{Resumen}

En un mundo cada vez más urbanizado, los gobiernos locales tienen mayor responsabilidad de implementar medidas prácticas frente al cambio climático. Medidas que ayuden a prevenir, mitigar y superar eficientemente eventos como las inundaciones, centrándose en el desarrollo urbano sostenible. El presente proyecto se enfoca en la ciudad de Tunja, Colombia. Se evalúan sectores con alta amenaza de inundación, según los principales cuerpos de agua que atraviesan el área urbana: los ríos Jordán y La Vega. El propósito de la investigación es proporcionar estrategias que promuevan la correcta gestión del riesgo de inundación en el municipio. Se cuenta con tres temáticas prioritarias: (1) la importancia de la planificación y gestión urbana; (2) el estudio de la 
vulnerabilidad desde la percepción social de los habitantes expuestos y, finalmente, (3) una propuesta de alternativas estratégicas según el riesgo analizado. Está dirigido a la promoción oportuna de la prevención y la reducción de afectaciones, producto de eventos de precipitación por variabilidad climática.

Palabras clave: desarrollo urbano sostenible, gestión de riesgos, inundaciones, percepción social, vulnerabilidad.

Received: $01 / 07 / 2019$

Accepted: 15/09/2020

\section{Introduction}

In the global context, people are choosing to settle in urban areas. Cities are currently considered as the engines of economic growth. People who migrate from rural to urban centers, pursue a higher standard of living. However, it must not be ignored the need to address climate change with risk management help and promotion. Cities that tend to grow significantly over years may bring increases in the regional economy, but they can also generate dangers if they are not planned and developed properly, in accordance with the environment that surrounds them. 
The need is emphasized in establishing better-planned cities and, above all, dignified and safe for their inhabitants. While the World Meteorological Organization reveals that nine out of ten disasters in the world are related to climate or water, natural disasters continue to have greater repercussions in the economies of developing countries. In Colombia, the precipitation events consequences due to the "La Niña" phenomenon, which has been one of the strongest in history (Hurtado \& Euscátegui, 2012), show the existing national flaws in terms of territorial organization. For this reason, it is of great importance that continuous monitoring of water bodies be generated and natural disasters that affect lives, infrastructure, and goods are prevented.

In Tunja, some risks may affect the population, assets, and infrastructure existing in the territory. Among which, it can be mentioned floods, landslides, seismic events, public agglomerations, technological risks, and of course, those derived from the effects of climate change, etc. These risks, of different origins and different forms in their manifestation, represent challenges for public policy, which must be coherent with the institutional transformations that have taken place in the country in recent years. With the Law 1523 of 2012 issuance, the conceptualization that up to that point had been made regarding disaster prevention was transformed, thus conceiving risk management as a social process.

It is for the needs previously exposed that this study is developed. Several processes framed in research, action, and participation are highlighted. Processes as a collection of data to analyze, review of documentary information provided by official entities, the study of priority 
areas to be evaluated, the use of techniques such as interviews, field visits, the recognition of selected sectors and finally, this project evaluate Flood Risk Management in the study area, providing a proposal of strategic guidelines for its application in the municipality of Tunja. This study is also analyzed local risk management, from the risk identification and perception, risk reduction, disaster management, and governance. All this, being very useful for the decision-making entities and for the same community that may be affected by disaster situations.

The document will have an analytical and descriptive character, focusing on the generation of theoretical and practical contributions in the scope of Flood Risk Management in Tunja's areas with the high threat. The most important periods of analysis for this research, are mainly those that occurred in 2010-2011 when the "La Niña" phenomenon was presented in Colombia and the subsequent legal advances that emerged. It is hoped that with this project results, improvements will be made in prevention and mitigation of damages activities resulting from future natural phenomena that may generate disasters in sites with high flooding threat.

\section{Literature review}

\section{Flood risk reduction methodologies}


2021, Instituto Mexicano de Tecnología del Agua

Open Access bajo la licencia CC BY-NC-SA 4.0 (https://creativecommons.org/licenses/by-nc$\mathrm{sa} / 4.0 /)$

\section{Risk management Departmental plans}

Within the Methodological Guide for the elaboration of Risk Management Departmental Plans, the state bets to the correct management of every risk, to the service of territory. The National Disaster Risk Management Policy is adopted and promoted in Colombia, by Law 1523 of 2012. These plans provide guidelines for the threats study, vulnerabilities, and risk, to establish actions to be carried out in each territory. This guide highlights the need for regional administrations to initiate and maintain the continuity of risk management processes in each sector, as well as integration in development planning, priority actions in this area, and other instruments of planning (PNUD, 2012).

\section{Sustainable Urban Drainage Systems (SUDS)}

Green growth and adaptation to climate change become a fundamental objective within the strategy of improving rainwater harvesting and retention systems. Since one of the risks associated with climate change 
2021, Instituto Mexicano de Tecnología del Agua

Open Access bajo la licencia CC BY-NC-SA 4.0 (https://creativecommons.org/licenses/by-ncsa/4.0/)

is the one caused by the floods, which have their origin in the inadequate management of surface run-off, in recent years it has been forced to raise in-depth discussion, wherefrom public policies and technical solutions, it provides the necessary tools to deal with these types of situations in a correct way.

One of the most influential factors in which surface runoff due to rain becomes a determining factor in the cities' flooding processes, has to do with the rapid urban growth, which due to the high number of buildings exceeds the networks of sewerage capacity. The lack of citizen culture, which generates sinks blockages due to pollution and the increase of impervious surface in public space, which do not contribute to retaining water but, on the contrary, evacuate it directly and more quickly to the city sewer networks. The need is to implement solutions according to the environment with low negative impact.

Through the Sustainable Urban Drainage Systems (SUDS) implementation, it is intended that the hydrological response of an urbanized area be as similar as possible to that in its hydrological original state (Ramos, Pérez-Sánchez, Franco, \& López-Jiménez, 2017). With the SUDS, two objectives are strengthened regarding the management of rainwater. On one hand, there is the redistribution of urban runoff through measures such as control at the source, the attenuation of flood peaks, the delivery of controlled/regulated discharges, the recharge of the aquifer, and the use of the flow transport. A second objective is the reduction of the contamination of water bodies receiving urban runoff. 


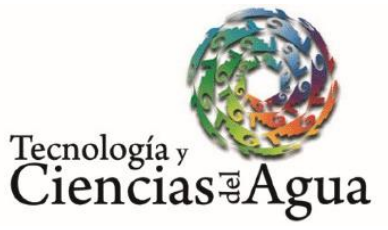

2021, Instituto Mexicano de Tecnología del Agua

Open Access bajo la licencia CC BY-NC-SA 4.0 (https://creativecommons.org/licenses/by-nc$\mathrm{sa} / 4.0 /)$

\section{Hydrodynamic modeling}

Thanks to computational advances, hydrological modelling has presented notable advances in the characterization of physical processes, as an extension of the application of concepts that enclose the behavior of water in its various phases of the hydrological cycle on the planet. There are works focused on the study of models that closely approximate the general hydrological processes taking into account surface areas, underground in hydraulic bases based on finite volume schemes, applying the complete Saint-Venant equations or simplifications (Caro-Camargo, \& Velandia-Tarazona, 2019). It has been observed that by applying the vertical transfer hydrological module into Iber software, the behavior of a basin has been approximated, resulting in accurate hydrological responses, showing special interest in the mesh type of the digital elevation model. It influences the results, the performance of the simulation, and the choice of type of hydrological or hydraulic modelling (Caro-Camargo, Pacheco-Merchán, \& Sánchez-Tueros, 2019).

Models that have been used in nations with excessive urban growth, allow confronting parameters of surface runoff and normal routing of the flow-through natural water channels that cross cities. Models that evaluate the main data that influence the behavior of flood risk warning systems have been proposed to prevent loss of human lives and deterioration of people's material goods (Chen, Zhou, Zhang, Du, \& Zhou, 2015). 


\section{Flood Early Warning Systems (FEWS)}

The devastating results that have been caused by floods have managed to generate an impact on both environment and society. In various parts of the world, tools for early warning have been studied since the frequent flood events. The need is observed in the timely response capacity that the affected localities can have. Some studies propose a flood index based on satellite data that identify areas that give rise to runoff and that contribute greatly to the production of flooding of the basin. The preliminary conclusions of the studies indicate that spatial distribution of areas that probably cause runoff, show the most prone flooding sites (Koriche \& Rientjes, 2016).

\section{Public management and Flood Risk Management}

To achieve a vulnerability reduction of flood's socio-natural phenomenon, it is necessary that strategies that are proposed and used have the maximum possible effectiveness. Regulatory instruments are needed that 
2021, Instituto Mexicano de Tecnología del Agua Open Access bajo la licencia CC BY-NC-SA 4.0 (https://creativecommons.org/licenses/by-nc$\mathrm{sa} / 4.0 /)$

focus on risk management and territorial ordering variables, maximizing the impact of population activity as priority criteria related to public, urban, and risk management.

\section{Materials and methods}

The methodology developed for this research was focused on 4 stages designed to meet the specific objectives established for the project. Below is shown a diagram in Figure 1 that summarizes the activities that will be described in the course of the article.

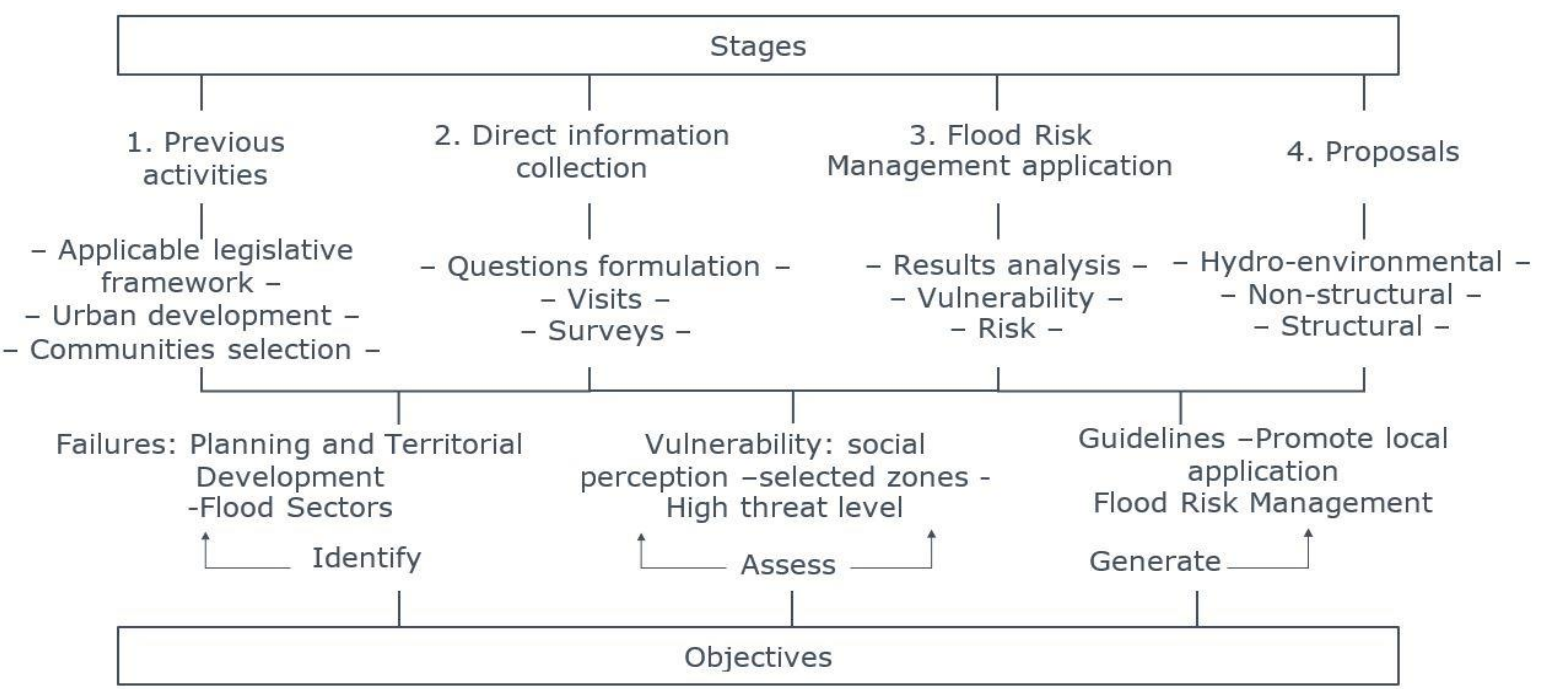

Figure 1. Research Methodology, Stages, and Objectives. Source: Own. 
It is clarified that the results obtained from each stage will be named here, but they remain in the development of the definitive book of this investigation. In this article, the most relevant approaches obtained will be highlighted.

\section{Location}

Tunja is the capital of the Boyacá department, located two hours from Bogotá, Colombia. The quality of urban space produced to the north of Tunja does not reach great levels, because despite locating in areas of high strata, studies focused on the lines of urban' design and transformations, reach to show that configuration of these sectors do not guarantee the adequate appearance of public spaces, nor their articulation with the system of facilities, nor their transition between built and natural means, nor with adequate access and communication routes with the rest of urban sectors. Normally, it is shown that the city configuration process, is under the regulation that focuses on determining occupancy rates of each property and does not show a consistent image with the needs of Urban Development that are currently indicated in studies at national and international levels (Chocontá-Martínez, 2017). In Figure 2 it is shown the city location. 
Tecnología y

Ciencias Agua
2021, Instituto Mexicano de Tecnología del Agua

Open Access bajo la licencia CC BY-NC-SA 4.0 (https://creativecommons.org/licenses/by-nc$\mathrm{sa} / 4.0 /$ )
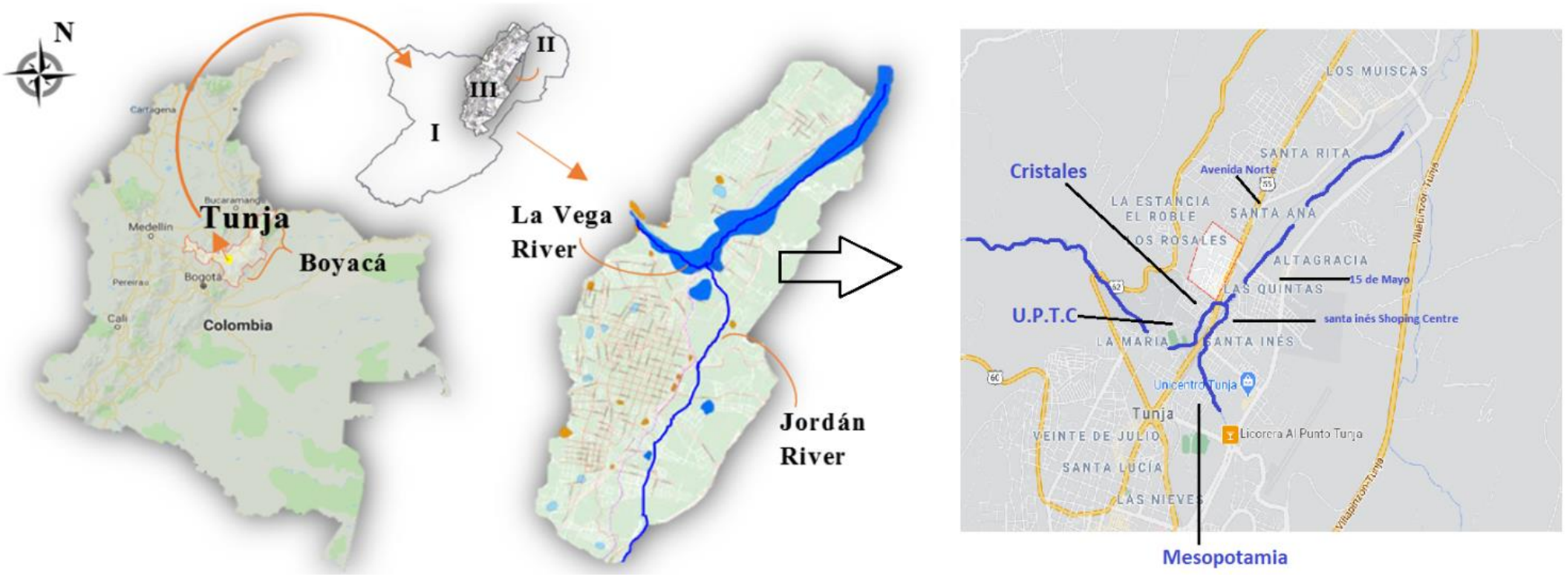

Figure 2. Case study location, Tunja, Colombia. Source: Own using Google Maps, TuSIG platform, Tunja POT.

Three main areas are shown, (I) Rural area, (II) Urban Expansion area, and (III) Urban area. The flood footprint during the "La Niña" phenomenon is also shown at the right of Figure 2 which corresponds to the prioritized urban area to study for its continuous growth and current development. Bearing in mind that the main neighborhoods affected by floods have been located, five of them were selected to study vulnerability from a social perspective (Las Quintas + José de Las Flores, 15 de Mayo, Santa Inés, Pozo Donato and Mesopotamia). 


\section{Points of interest for possible overflow}

There are specific stretches on riverbanks that have lower elevations on certain hillsides and may affect neighborhoods when rainfall events occur, with high return periods. These specific points have been approached under hydrodynamic modelling and those found in this case study were selected. Below in Figure 3 are some of the most vulnerable points to overflow at a Return Period $T=50$ years, according to the IBER modelling carried out in previous studies (Caro-Camargo \& Bayona-Romero, 2018). 
Tecnología y

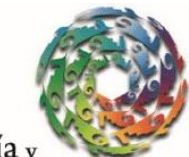

Ciencias Agua
2021, Instituto Mexicano de Tecnología del Agua

Open Access bajo la licencia CC BY-NC-SA 4.0 (https://creativecommons.org/licenses/by-nc$\mathrm{sa} / 4.0 /)$

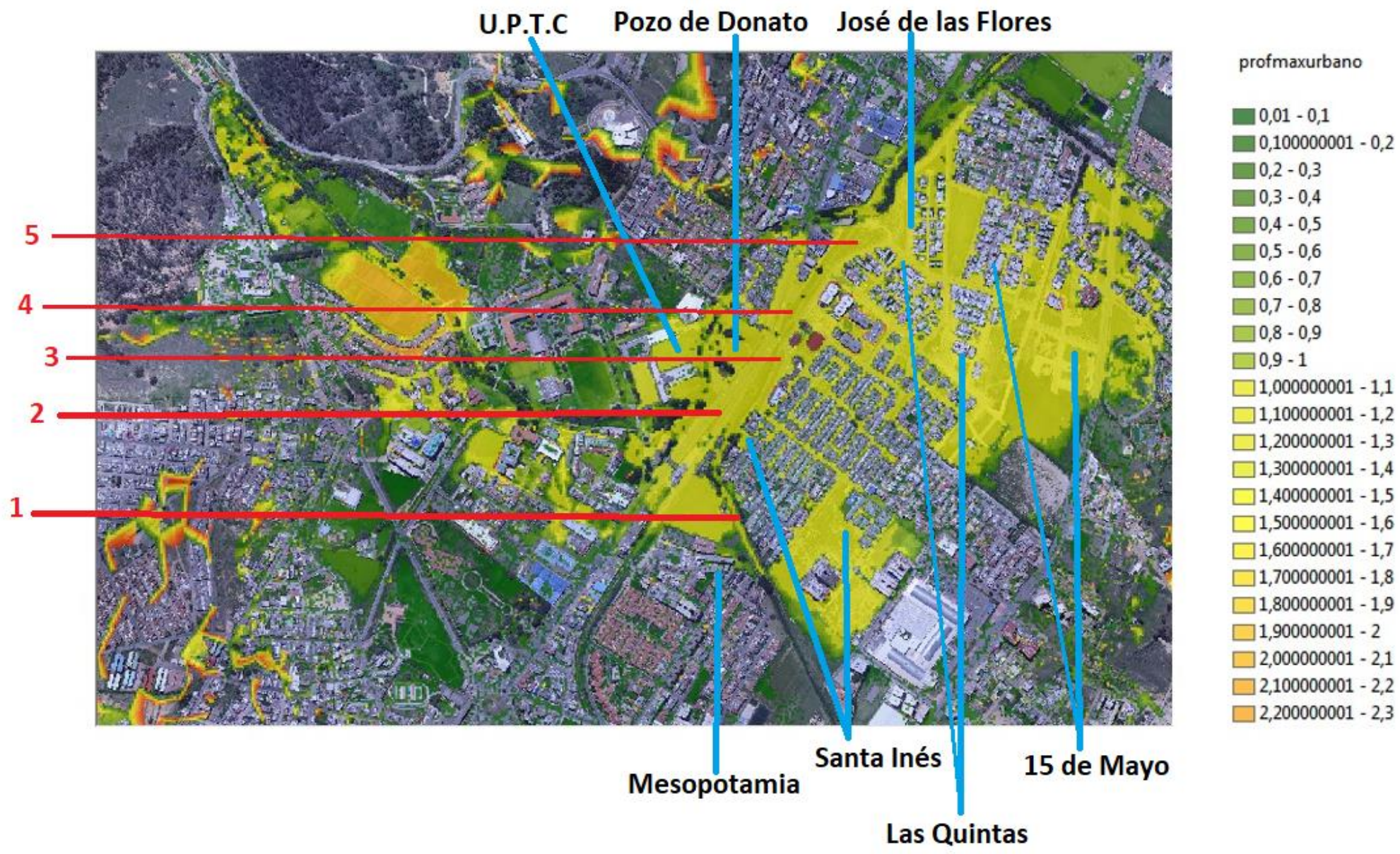

Figure 3. Points of interest. Possible overflows. Source: Own, according to the IBER modelling.

- The first point is located on the Jordán Alto River stretch, which crosses between the Mesopotamia neighborhood and the Santa Inés neighborhood. According to the transversal profile, it is observed that the level of Mesopotamia is much lower than that adjacent to the area of Remansos de Santa Inés, which generates flood threats to the first neighborhood with water drafts up to $1.3 \mathrm{~m}$ and speeds of $0.8 \mathrm{~m} / \mathrm{s}$. 
- The second point of interest for this study is located between the Avenida Norte and Santa Inés neighborhood, which has a lower height towards the slope of the avenue, in front of the Pedagogical and Technological University of Colombia (UPTC), what can be affected with dimensions of $0.5 \mathrm{~m}$ and speeds of $0.5 \mathrm{~m} / \mathrm{s}$.

- The third point observed in the study was the one that generates a $90^{\circ}$ turn in the Jordán River, at the height of Santa Inés Shopping Centre. This may affect the area of Santa Inés and Quince de Mayo, with flood levels and speeds similar to those mentioned in the previous point.

- For the fourth revised point, there is a great contextualization due to flood events in the past, which have affected neighborhoods such as Los Rosales, Los Cristales, Pozo Donato, and Avenida Norte. It is located on the La Vega River and generates a reduction in the river section, due to the location of a Box Culvert structure. According to the results of the model, speeds of $0.8 \mathrm{~m} / \mathrm{s}$ and drafts of up to $1.5 \mathrm{~m}$ are given, which makes it a high hazard zone.

- Finally, the fifth point refers to the sector of the Jordán Bajo River (after its union with the La Vega River), at the height of Las Quintas, where an overflow to the east can occur, with water sheet elevations up to $1.5 \mathrm{~m}$ above the ground. This flood of the area would have the ability to reach University Avenue and the areas that are currently in process of urban development.

This study was reviewed and corroborated, to present later, suggestions for structural measures to be taken. 
Tecnología y

Ciencias $₫$ Agua
2021, Instituto Mexicano de Tecnología del Agua

Open Access bajo la licencia CC BY-NC-SA 4.0 (https://creativecommons.org/licenses/by-nc$\mathrm{sa} / 4.0 /)$

\section{Sample}

Through the development of this section, constant use was made of the Generic Statistical Business Process Model (GSBPM v 5.1), where suggestions are presented to apply statistical models in various case studies. The structure presented by this model is defined by eight stages of development that are shown in Figure 4. The model is designed to be used in describing and evaluating the quality of processes based on surveys, censuses, administrative records, and other non-statistical or mixed sources (UNECE, 2019) Due to its extensive applicability, updating and wide adaptation condition according to each case study, this model was selected to be used in this investigation.

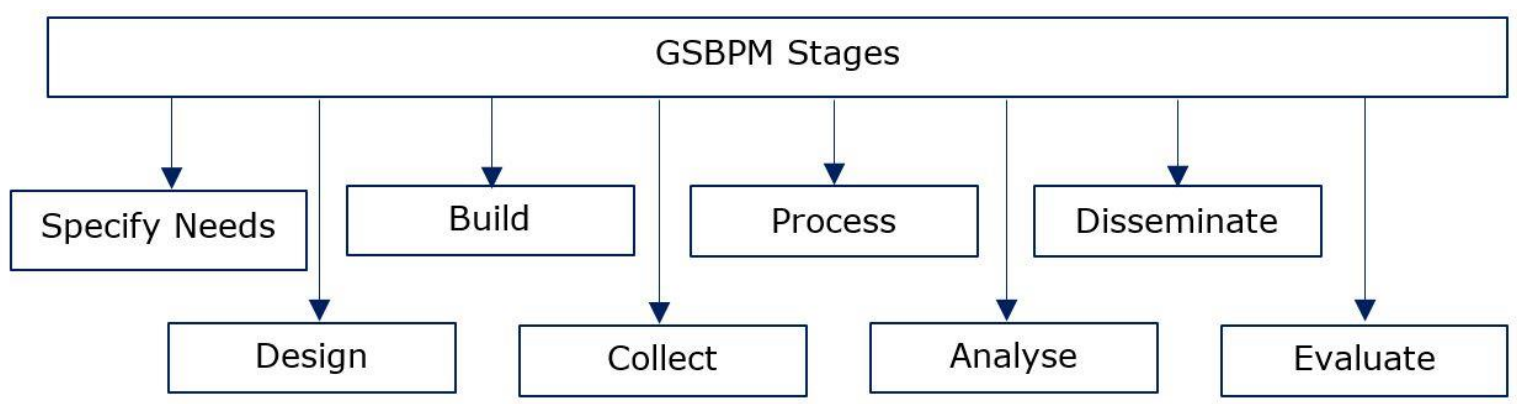

Figure 4. Level 1GSBPM Stages. Source: Own, according to the Model. 
Tecnología y

Ciencias $₫$ Agua
2021, Instituto Mexicano de Tecnología del Agua

Open Access bajo la licencia CC BY-NC-SA 4.0 (https://creativecommons.org/licenses/by-ncsa/4.0/)

Sixteen questions were selected to apply during the inhabitant's interviews. About 15 more were directed to agent entities of Municipal Risk Management.

As the first section of the survey format, the characterization of households was taken, followed by the dwelling and its surroundings, the threat' perception and memory, to end with a section of the spatial location of the sector inhabitants, generated through a visual activity of the municipality, the neighborhood and its housing. The first three sections were assembled in a template created using Google Forms and they were applied with the university institutional mail so that the information was recorded and updated at the time on the Internet.

After having the number of built properties, was proceeded to randomly select the sample, according to the amount that was given by the calculation of the sample size, shown in Table 1 . This sample was made for the sum of the built properties that were counted (Sectors 1 and 2).

Table 1. Surveys number per Sector.

\begin{tabular}{|c|c|c|c|c|}
\hline Neighborhoods & $\begin{array}{c}\text { Households } \\
\text { number }\end{array}$ & Percentage & $\begin{array}{c}\text { Surveys } \\
\text { number }\end{array}$ & $\begin{array}{c}\text { Surveys } \\
\text { taken }\end{array}$ \\
\hline Sector 1 & 621 & $100 \%$ & 65 & 65 \\
\hline $\begin{array}{c}\text { Las Quintas + } \\
\text { José de las Flores }\end{array}$ & 571 & $92 \%$ & 60 & 10 \\
\hline Pozo Donato & 50 & $8 \%$ & 5 & 69 \\
\hline Sector 2 & 1303 & $100 \%$ & & \\
\hline
\end{tabular}


2021, Instituto Mexicano de Tecnología del Agua

Tecnología y

Ciencias $\stackrel{\Xi}{\longleftarrow}$ Agua
Open Access bajo la licencia CC BY-NC-SA 4.0 (https://creativecommons.org/licenses/by-nc$\mathrm{sa} / 4.0 /)$

\begin{tabular}{|c|c|c|c|c|}
$\begin{array}{c}\text { Santa Inés }+15 \\
\text { Mayo }\end{array}$ & 739 & $57 \%$ & 39 & 43 \\
\hline $\begin{array}{c}\text { Santa Inés }+ \\
\text { Mesopotamia }\end{array}$ & 564 & $43 \%$ & 30 & 32 \\
\hline
\end{tabular}

Source: Own, according to the sample.

\section{Results}

\section{Analysis of the carried out surveys}

It was observed that the 150 surveys carried out, represent 519 people living in dwellings of sectors under study. On average there are 4 inhabitants per household and women represent a greater number. The sectors mostly have people over 45 years, followed by young people between 18 and 25 who are mostly university students. The inhabitants of studied sectors have jobs - whether independent or employees - and most have reached the development of university studies. 
For emergencies, it is observed that none of the sectors recognizes a clear and structured evacuation route. About $20 \%$ of them say they know one, but they do not have a clear meeting point with home inhabitants of the neighborhood. There were very few homes that had established points, in some cases not very convenient, to meet with the family members.

Regarding one of the questions about flood threat memory, it was observed that $72 \%$ of Sector 1 inhabitants say they do not remember suffering from flood events. This is because a large number of the population of the Las Quintas neighborhood has not lived there for more than 5 years. However $70 \%$ of the respondents in the Pozo Donato neighborhood, along with $21 \%$ of Las Quintas neighborhood who answered affirmatively to this question, remember the events that occurred during the winter season-"La Niña" phenomenon, which occurred in 2010-2012.

\section{Threat assessment}

The threat is a risk factor associated with a physical event of natural origin, caused or induced by human action. This can occur with sufficient severity to cause loss of life, property, or health impacts. Threats can be associated with their natural origin (inherent in planet natural dynamics), 
Tecnología y

Ciencias $\stackrel{\unlhd}{\text { Agua }}$
2021, Instituto Mexicano de Tecnología del Agua Open Access bajo la licencia CC BY-NC-SA 4.0 (https://creativecommons.org/licenses/by-nc$\mathrm{sa} / 4.0 /)$

anthropic (directly human actions, both intentional and unintentional), technological (associated with industrial activities and transportation of hazardous substances), or socio-natural (similar to natural, but induced).

According to values obtained through surveys, the analysis of frequency, intensity, and affected territory was carried out, to find the threat value in the studied sectors, prioritizing events that occurred in 2011. During this stage, was used the methodological guide (PNUD, 2012), where 1 means Low assessment, 2 means Medium, and three means High. In Table 2 can be seen the threat global results:

Table 2. Threat assessment.

\begin{tabular}{|c|c|c|c|}
\hline Frequency & Intensity & Affected Territory & Threat \\
\hline 3 - High & 2 - Medium & 3 - High & 8 - High \\
\hline $\begin{array}{l}\text { The event } \\
\text { that occurs } \\
\text { more than } \\
\text { once in a } \\
\text { year or at } \\
\text { least once in } \\
\text { a period of } \\
\text { one to three } \\
\text { years }\end{array}$ & $\begin{array}{l}\text { Moderate affectation of } \\
\text { territory, natural } \\
\text { resources, affectation in } \\
\text { public services } \\
\text { networks, temporary } \\
\text { suspension of economic } \\
\text { activities, moderate } \\
\text { affectation in } \\
\text { infrastructure, damaged } \\
\text { houses }\end{array}$ & $\begin{array}{l}\text { More than } 80 \% \text { of the } \\
\text { studied territory has } \\
\text { been affected }\end{array}$ & $\begin{array}{c}\text { Frequency } \\
+ \\
\text { Intensity } \\
+ \\
\text { Affected } \\
\text { Territory } \\
\text { (1-3 Low, 4-6 } \\
\text { Medium, 7-9 } \\
\text { High) }\end{array}$ \\
\hline
\end{tabular}

Source: Own, according to the guide. 
It was obtained that the threat in which they are found is high. This corroborates the studies carried out on the municipality of Tunja, in which the maps show these communities with a high flood threat. Likewise, the faults that are generated in the sewage system can be added to it, which causes overflows to be recurrent in rainy periods.

\section{Vulnerability assessment}

After generating an analysis of the physical, environmental, economic, and social vulnerability, according to information collected about sectors understudy in Tunja, Table 3 shows the obtained total vulnerability for both sectors.

Table 3. Vulnerability assessment - Sum of vulnerabilities.

\begin{tabular}{|c|c|c|c|c|}
\hline $\begin{array}{c}\text { Physical } \\
\text { Vulnerability }\end{array}$ & $\begin{array}{c}\text { Environmental } \\
\text { Vulnerability }\end{array}$ & $\begin{array}{c}\text { Economic } \\
\text { Vulnerability }\end{array}$ & $\begin{array}{c}\text { Social } \\
\text { Vulnerability }\end{array}$ & $\begin{array}{c}\text { Total } \\
\text { Vulnerability }\end{array}$ \\
\hline $\begin{array}{l}\text { Sector 1: } 9 \\
\text { Sector 2: } 10\end{array}$ & $\begin{array}{c}\text { Both sectors: } \\
10\end{array}$ & $\begin{array}{l}\text { Sector 1: } 6 \\
\text { Sector 2: } 5\end{array}$ & $\begin{array}{l}\text { Both sectors: } \\
9\end{array}$ & $\begin{array}{l}\text { Both sectors: } \\
\mathbf{3 4} \text { - Medium }\end{array}$ \\
\hline $\begin{array}{l}\text { - Age of the } \\
\text { building } \\
\text { - Construction } \\
\text { materials and }\end{array}$ & $\begin{array}{l}\text { - Atmospheric } \\
\text { conditions } \\
\text { - Air quality and } \\
\text { composition }\end{array}$ & $\begin{array}{l}\text { - Income level } \\
\text { - Poverty and } \\
\text { food security } \\
\text { situation }\end{array}$ & $\begin{array}{l}\text { - Organization } \\
\text { level } \\
\text { - Participation }\end{array}$ & \\
\hline
\end{tabular}


Tecnología y

Ciencias $₫$ Agua
2021, Instituto Mexicano de Tecnología del Agua

Open Access bajo la licencia CC BY-NC-SA 4.0 (https://creativecommons.org/licenses/by-nc$\mathrm{sa} / 4.0 /)$

\begin{tabular}{|c|c|c|c|}
\hline $\begin{array}{c}\text { state of } \\
\text { preservation } \\
\text { - Compliance with } \\
\text { current } \\
\text { regulations } \\
\text { - Characteristics } \\
\text { of the type of soil } \\
\text { - Location of } \\
\text { buildings } \\
\text { concerning water } \\
\text { source zones and } \\
\text { identified risk } \\
\text { zones }\end{array}$ & $\begin{array}{c}\text { - Water quality } \\
\text { and } \\
\text { composition } \\
\text { - Conditions of } \\
\text { environmental } \\
\text { resources }\end{array}$ & $\begin{array}{l}\text { - Access to } \\
\text { public services } \\
\text { - Access to } \\
\text { the labour } \\
\text { market }\end{array}$ & $\begin{array}{c}\text { - Relationship } \\
\text { between } \\
\text { community, } \\
\text { organizations, } \\
\text { and } \\
\text { institutions } \\
\text { - Community } \\
\text { risk } \\
\text { knowledge }\end{array}$ \\
\hline
\end{tabular}

Source: Own, according to the guide.

\section{Risk assessment}

To make the risk calculation presented in the chosen sectors, the doubleentry matrix is used, of Threat and Vulnerability as shown in Table 4. Both results obtained previously are interrelated. The intersection of both estimates the expected risk level. This information is very important to adopt measures that can facilitate risk reduction and disaster management processes. 
Tecnología y

Ciencias $₫$ Agua
2021, Instituto Mexicano de Tecnología del Agua Open Access bajo la licencia CC BY-NC-SA 4.0 (https://creativecommons.org/licenses/by-nc$\mathrm{sa} / 4.0 /)$

Table 4. Risk assessment.

\begin{tabular}{|c|c|c|c|}
\hline \multicolumn{3}{|c|}{ Risk assessment matrix } \\
\hline Threat & & Risk \\
\hline High & Medium & High & High \\
\hline Medium & Low & Medium & Medium \\
\hline Low & Low & Low & High \\
\cline { 2 - 4 } & Low & Medium & \multicolumn{3}{|c|}{ Vulnerability } \\
\cline { 2 - 4 } & & \multicolumn{3}{|c|}{} \\
\cline { 2 - 4 } & &
\end{tabular}

Source: Own, according to the guide.

According to the threat results (high) and vulnerability (medium), obtained for the studied sectors, it can be seen that the risk estimation for these areas is high. Population, as well as corresponding institutions, must become aware and spread knowledge about the existing risk. It is necessary to take measures to mitigate possible future emergency events and apply them in conjunction with the sector's community and threatened by flood. When society increases its resilience, the conditions of vulnerability and its levels of risk will reduce.

\section{Proposals}


Some action proposals that when promoted, can reduce the existing vulnerabilities in flood threat sectors are presented. Taking into account that the characteristics of the study area correspond to sectors of rapid urbanization, low slope, and high risk of flooding, due to its proximity to water bodies and aquifer recharge areas, a series of strategies were proposed for proper planning and flood risk control. Below are the most relevant structural measures to be taken into account in these cases.

The structural measures that can be adopted for these sectors consider the construction of protection works on the banks. In the case study, it was possible to highlight the points of importance due to the overflow of the river, presented in Figure 3, in which the construction of walls, gabions, and/or pitchers on the riversides is proposed and recommended, 0.5 to $0.8 \mathrm{~m}$ above the current ground level.

\section{SUDS}

SUDS seek to work in different scenarios of the public space that by their vocation, can intervene efficiently. Although it is true that SUDS implementation strategies have been developed in some Colombian cities, as it is not a public policy, progress in their implementation is still little studied (Martínez-Candelo, 2014). Among the most used, it can be highlighted roofs, facades, and green ditches, which are based on the city 
2021, Instituto Mexicano de Tecnología del Agua

Open Access bajo la licencia CC BY-NC-SA 4.0 (https://creativecommons.org/licenses/by-ncsa/4.0/)

natural systems, not designed for that purpose but efficient, such as parks, sardine, separators, among others. However, in many cases, the percentage of the impermeable surface area is still much higher, compared to the desirable filtering surface for cities with these problems (Hoang \& Fenner, 2016).

These unconventional alternatives arise in response to similar problems to those associated with the Tunja municipality, where the impermeable city growth is increasingly greater soil percentages and there are limitations in the existing drainage systems.

In Tunja, the objective would be to adopt alternatives based on SUDS methodology, to control and regulate the runoff generated by rains by effectively integrating a detention pond, which temporarily stores the excess rainfall volume and delivers a comfortable flow to the sewer network. For all this, it must be known by the institutions responsible for its implementation, and the local community for proper care and maintenance.

When selecting and designing the proposed alternatives, having identified the project area, the urban information, topography, type of soils, and roads should be identified, proceeding to delimit the respective areas that will drain its runoff to the detention zone, determining each of its parameters, with which the hydrographs and flows generated by them can be calculated. In this way, the volume and type of regulation that best suits the local conditions are determined. All this can be simulated in software like EPA SWMM (free access), which has a SUDS extension to be modelling in urban environments (Jimenez, 2015). 
In Sector 1 it is recommended the implementation of flood plain park, since it is, by far, the system with the highest flow eliminate srom the drainage network with high water retention capacities, taking advantage of this way, the large available surface area that is effectively available for a recreational area. Additionally, it is important to mention that it is the point of arrival of the flow with high speeds coming from the city downtown (by topography), so a temporary retention reservoir, or in this case a flood park, fulfills the function of reducing speeds for sectors down thus also reducing the associated vulnerabilities.

\section{FEWS}

It is of great importance that Flood Early Warning Systems (FEWS) implementation, be promoted for the benefit of populated areas at risk of flooding (González-Cao, García-Feal, Fernández-Nóvoa, DomínguezAlonso, \& Gómez-Gesteira, 2019). During the development of this investigation, it was observed that Tunja has a high risk of flooding in certain zones. Most of its floods in urban areas are due to overflows of sewers, but the most impacting events for the community have been in conjunction with the overflow of water bodies that cross it. This increases the need to have a timely and adequate information system on river levels at strategic points, where possible affectation downstream is 
Ciencias $₫$ Agua
2021, Instituto Mexicano de Tecnología del Agua

Open Access bajo la licencia CC BY-NC-SA 4.0 (https://creativecommons.org/licenses/by-nc$\mathrm{sa} / 4.0 /)$

demonstrated. All this, to be forewarned and be able to make the best on-time decisions.

This measure can increase the security level for the Tunja's urban area inhabitants, who are located on riverbanks, and efficiently plan their action steps. For the FEWS implementation project, this proposed methodology can be followed:

- Collect topographic and hydro-climatological information of the study area.

- Determine environmental and hydrodynamic variables for an early warning system in the case study.

- Modelling the hydrodynamic and environmental study area, using hydrodynamic models (e.g. IBER), to analyze the water bodies behavior.

- Establish significant points to implement early warning systems.

Based on exhaustive FEWS research, it is proposed to consider the following two phases, predesign and design, for flood studies in localized areas.

Pre-design: It is proposed to select the object of the alert, considering the frequency, the type, and the arrival times of floods. Drainage areas (basins and sub-basins) must be delimited. Information is collected (Cartographic, meteorological and hydro-climatological). Then, the hydrological characterization of the basin and the field survey are carried out, for the preparation of a complete report.

Design: During the design phase, it establishes the type of FEWS and its components, with the preparation of instrumentation such as rain gauges. A hydrodynamic analysis of the sites of interest is carried out, 
2021, Instituto Mexicano de Tecnología del Agua

Open Access bajo la licencia CC BY-NC-SA 4.0 (https://creativecommons.org/licenses/by-ncsa/4.0/)

with hydrological and hydraulic modeling topographies, the selection of flood thresholds is made and an operating protocol is made. This, to finally develop a feedback process in the FEWS implementation process.

Within the research carried out, on the FEWS implementation methodologies, can be a highlight this summary, which may be complementary to the revision at the time of implementation of a system for the municipality of Tunja.

FEWS operation can be divided into three components, monitoring, communications, and alert activation, to make way for the response preparations. For monitoring, FEWS have transmission and data collection equipment that includes the rain gauges and the level sensors, linked to the hydro-meteorological network of the city where they are installed. This allows the realization of hydro-meteorological behavior and favoring the forecast models of the basin.

It is important to adequately zoning the rainfall registered in the municipality of Tunja. Risk Management entities, keep track of the rains, however, according to information processed with the municipal entity, there have been months without data, being the most rainy. Generate reliability about rainfall measurements, benefits the knowledge of events occurring in the territory and its timely management.

The way of monitoring that Tunja currently has to face possible overflows, is by means of revision the river levels in certain points, which are watched in rain periods by the municipal aid agents. 


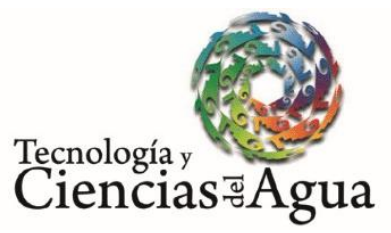

2021, Instituto Mexicano de Tecnología del Agua

Open Access bajo la licencia CC BY-NC-SA 4.0 (https://creativecommons.org/licenses/by-ncsa/4.0/)

\section{Discussion}

During the development of this research work, the idea that risk is socially constructed due to multi-causal phenomena was maintained. This implies that several factors that take place in the same territory, make the disastermaterialize. In this final section, the fulfillment of the established objectives, the initial research questions raised will be reviewed and some final comments will be pointed out.

According to the obtained results from this project, the main processes were taken throughout its development and the specific objectives were analyzed to review its derivations:

- Within the identification of existing shortcomings in the territorial development of Tunja and its current situation in Flood Risk Management, it was possible to choose 5 priority neighborhoods to be analyzed, due to being under a high threat of flooding and to have sufficient information on the buildings developed in this study area. Finally, a recognition of the sector was generated, making a summary of their current situation.

- Regarding the evaluation by means of surveys of the existing vulnerability, from the social perception, in the chosen areas for their flood high threat level events in Tunja, it was possible to carry out a direct information collection, which determined the needs and established the flood vulnerability from social perception. With all this, an accurate number of surveys was obtained, with a sample of 150, representing 519 people, and a summary of the results obtained was made, as well as the 
Tecnología y

Ciencias $₫$ Agua
2021, Instituto Mexicano de Tecnología del Agua Open Access bajo la licencia CC BY-NC-SA 4.0 (https://creativecommons.org/licenses/by-nc$\mathrm{sa} / 4.0 / \mathrm{l}$

evaluation of the Flood Risk, based on various variables. The flood threat turned out to be high for these sectors, which in combination with their Medium vulnerability, generated a High risk.

During the answers analyze, one question decided to be highlighted. It was observed that most communities do not consider that the municipality is prepared to deal with emergency situations that may arise, as results shown in Figure 5 . This perception is very important to take community approach measures by the in-charge institutions.

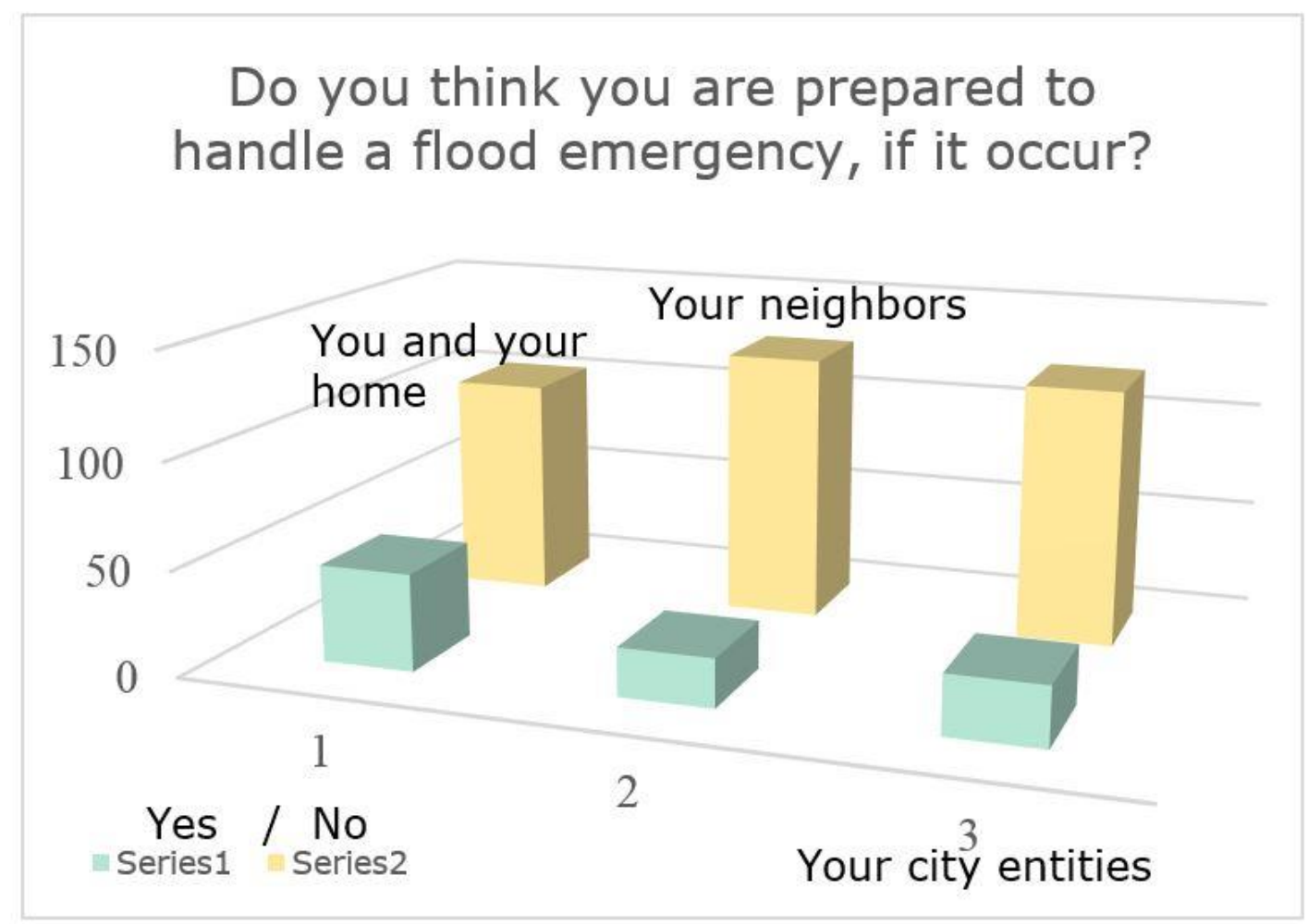

Figure 5. Social perceptions about municipality preparation against flood risk. Source: Own, according to the survey. 
2021, Instituto Mexicano de Tecnología del Agua

Open Access bajo la licencia CC BY-NC-SA 4.0 (https://creativecommons.org/licenses/by-ncsa/4.0/)

- Regarding the generation of theoretical and practical knowledge that promotes the local application of Flood Risk Management in Tunja, according to the developed analyses, relevant content was presented as alternatives to be applied in high threat sectors. The need to install Flood Early Warning Systems was raised, promoting a methodology from its design. The implementation of methodologies studied and successfully applied in localized areas of this type is promoted (Robleto-Molina, 2010). At the same time of all the above, knowledge acquired through research was shared, around different methodologies and actions are taken that also promote the mitigation of flood events, through the implementation of Urban Systems of Sustainable Drainage, which can reach to be deepened and applied at the local level, promoting adequate management of rainwater, its retention, cleaning, and use. The proposal for a floodable park means that there is no flooding immediately downstream of Sector 1 which has also been verified in similar studies (Trapote-Jaume \& Fernández-Rodríguez, 2016).

Although these systems may not be the definitive solution to the city flood problems, they would generate great benefits for the sewerage systems, which currently generate problems when it comes to heavy rainfall events.

The complementation of the information presented is recommended, in future studies, with the 50 guidelines for the design of SUDS (Departamento Nacional de Planeación, 2018) and the specific technical guides by Los Andes University, the EAAB, and the Secretaría de Ambiente de Bogotá (Universidad de Los Andes, 2017), since they are ideal technical documents for the development of these research and 
application works, being able to obtain great benefits for the inhabitants of the threatened sectors and their governments.

With this project, the aim is for official entities to take as a basis the information presented, to project socializations, workshops, and other strategies to create a preventable and resilient community in the face of existing local threats; increase knowledge of risk management issues in Tunja city, according to their threats. In addition, it was ensured that inhabitants who were interviewed during the development of this project, could become more aware about their flood vulnerability and the need to expand their knowledge on the subject, bearing in mind that they will generate their own benefit.

\section{Conclusions}

Through the present study, it was possible to determine high risk for the studied areas, where the implementation of unstructured proposals is required, such as education and taking legal and governmental measures against risk, as well as the construction of structural solutions, such as gabions, SUDS and FEWS. This, taking into account that the inhabitants exposed downstream of the water bodies would benefit. 
2021, Instituto Mexicano de Tecnología del Agua

Open Access bajo la licencia CC BY-NC-SA 4.0 (https://creativecommons.org/licenses/by-nc$\mathrm{sa} / 4.0 /)$

SUDS restore in the city the natural hydrological cycle to maintain the hydrology prior to the urbanization process, minimizing runoff and impacts of urban planning, improving the landscape integration of the city and its infrastructures, improving services to the citizen in a respectful way with the environment.

In the case of Tunja, the company providing water and sewage services, together with the municipal planning secretary, should join efforts to define and establish unified criteria applicable to new urban constructions that allow the adoption of this type of project, SUDS alternatives, including structural and non-structural measures. This work requires at the same time a complete diagnosis of the real state of the city sewer system.

It is expected that communities achieve great progress in reaching the general objectives of risk management plans, including an increase in flood risk perception and self-protection strategies. To improve administrative coordination between involved actors, flood predictive capacity, and reduction of the danger as far as possible to the health of population, environment, and economic activities in flood zones.

Effective implementation of Disaster Risk Reduction and Disaster Risk Management systems depends on the strength of institutional capacities and key actors at different levels of government, private sector, and civil society and effective coordination between these. The promotion of good social practices at local levels is required, particularly in environmental management, appropriate use of land and natural resources, urban management, and comprehensive risk management, which are the product of historical processes of relationship and 
Ciencias $₫$ Agua
2021, Instituto Mexicano de Tecnología del Agua

Open Access bajo la licencia CC BY-NC-SA 4.0 (https://creativecommons.org/licenses/by-nc$\mathrm{sa} / 4.0 /)$

adaptation with the environment of local knowledge, scientific development at a specific level and public administration activity at the municipal level.

It is expected that this work will motivate the realization of future research for urban areas, where powerful analysis tools will be provided and, with interdisciplinary teams and greater resources, spatial monitoring of vulnerabilities to natural threats can be made, in order to have better-planned cities, but above all, more "dignified and safe", with populations more aware of their role, both in the generation and in the prevention and reduction of vulnerability conditions.

It is worth mentioning that there are no infallible proposals that guarantee success by defining and involving society in general, with its assets and the need to protect the public. Less in this scenario that is dominated by uncertainty. However, by generating joint efforts for the incorporation and dissemination of the idea that the problem of floods is not in isolated scenarios, but is part of our territorial system, it would be understood that local scale is the basis for developing disaster reduction comprehensive strategies. Following coordination, cooperation, and flexibility principles in the strategies adoption, it will be possible to define an efficiently route oriented towards the achievement of a common good, within a sustainable context.

Will is required, accompanied by a paradigm shift that involves the management of public infrastructure in cities sustainable development. Promotion to the knowledge of existent risks for those that can get to be mostly affected and a development perspective extension, aimed for the population needs. Within this study, it can be pointed out main results for 
its treatment in conjunction with various entities, from social awareness, work in the community, as a prospective vision of urban design responsible.

\section{References}

Caro-Camargo, C. A., Pacheco-Merchán, O. F., \& Sánchez-Tueros, H. P. (2019). Calibration of Manning's roughness in non-instrumented rural basins using a distributed hydrological model. DYNA, 86(210), 164-173. DOI: https://doi.org/10.15446/dyna.v86n210.72506

Caro-Camargo, C. A., \& Velandia-Tarazona, J. E. (2019). The effect of changes in vegetation cover on the hydrological response of the sub-basin Los Pozos. DYNA, 86(208), 182-191. Recovered from https://doi.org/10.15446/dyna.v86n208.74115

Caro-Camargo, C. A., \& Bayona-Romero, J. A. (2028). Hydro-dynamic modeling for identification of flooding zones in the city of Tunja. Revista Facultad de Ingeniería, 88, 40-55. DOI: https://doi.org/10.17533/udea.redin.n88a05

Chen, Y., Zhou, H., Zhang, H., Du, G., \& Zhou, J. (2015). Urban flood risk warming under rapid urbanization. Environmental Research, 193, 3-10. DOI: $10.1016 /$ j.envres.2015.02.028

Chocontá-Martínez, M. J. (2017). Morfología urbana. Acercamiento de la teoría a la práctica. Configuración de las zonas de expansión en el norte de Tunja. Bogotá, Colombia: Universidad Nacional de Colombia. 
Teçnología y

Ciencias Agua
2021, Instituto Mexicano de Tecnología del Agua

Open Access bajo la licencia CC BY-NC-SA 4.0 (https://creativecommons.org/licenses/by-nc$\mathrm{sa} / 4.0 /)$

Departamento Nacional de Planeación. (2018). 50 Lineamientos para el Diseño de Sistemas Urbanos de Drenaje Sostenible SUDS. Bogotá: DNP, Departamento Nacional de Planeación.

González-Cao, J., García-Feal, O., Fernández-Nóvoa, D., DomínguezAlonso, J. M., \& Gómez-Gesteira, M. (2019). Towards an automatic early warning system of flood hazards on precipitation forecasr: The case of the Miño River (NW Spain). Natural Hazards and Earth System Sciences, 19(11), 2583-2595. DOI: 10.5194/nhess-192583-2019

Hoang, L., \& Fenner, R. A. (2016). System interactions of stormwater management using sustainable urban drainage systems and green infraestructure. Urban Water Journal, 13(7), 739-758. Recovered from https://doi.org/10.1080/1573062X.2015.1036083

Hurtado, G., \& Euscátegui, C. (2012). Análisis del impacto del fenómeno "La Niña" 2010-2011 en la hidroclimatología del país. Recovered from

http://www.ideam.gov.co/documents/21021/418818/An\%C3\%A1l isis+Impacto+La+Ni\%C3\%B1a.pdf/640a4a18-4a2a-4a25-b7d5b3768e0a768a

Jimenez, A. F. (2015). Sistemas urbanos de drenaje sostenible (SUDS) como gestión integral en la regulación y control de aguas lluvias; caso de estudio sector en la ciudad de Bogotá. Bogotá, Colombia: Universidad Católica de Colombia.

Koriche, S. A., \& Rientjes, T. H. M. (2016). Application of satellite products and hydrological modelling for flood. Physics and Chemistry of the Earth, 93, 12-23. 
Tecnología y

Ciencias Agua
2021, Instituto Mexicano de Tecnología del Agua

Open Access bajo la licencia CC BY-NC-SA 4.0 (https://creativecommons.org/licenses/by-nc$\mathrm{sa} / 4.0 / \mathrm{l}$

Martínez-Candelo, G. (2014). Sistemas urbanos de drenaje sostenible "SUDS" como alternativa de control y regulación de las aguas Iluvias en la ciudad de Palmira. Bogotá, Colombia: Universidad Militar Nueva Granada.

PNUD, Programa de las Naciones Unidas para el Desarrollo. (2012). Guía metodológica para la elaboración de planes departamentales para la Gestión del Riesgo. Bogotá, Colombia: Programa de las Naciones Unidas para el Desarrollo- Unidad Nacional para la Gestión del Riesgo de Desastres, Unión Europea.

Ramos, H. M., Pérez-Sánchez, M., Franco, A. B., \& López-Jiménez, P. A. (November, 7, 2017). Urban Floods Adaptation and Sustainable Drainage Measures. Fluids, 2, 61. DOI: 10.3390/fluids2040061

Robleto-Molina, J. A. (2010). Metodología para el diseño e implementación de sistemas de alerta temprana ante inundaciones con aplicación hidrológica e hidráulica. Guatemala, Guatemala: Escuela Regional de Ingeniería Sanitaria y Recursos Hidráulicos.

Trapote-Jaume, A., \& Fernández-Rodríguez, H. (2016). Técnicas de drenaje urbano sostenible. Alicante, España: Instituto Universitario del Agua y de las Ciencias Ambientales.

UNECE, United Nations Economic Commission for Europe. (2019). Generic Statistical Business Process Model - GSBPM v 5.1. Geneva, Switzerland: United Nations Economic Commission for Europe, International Statistical Community.

Universidad de Los Andes. (2017). Guía técnica de diseño y construcción de sistemas urbanos de drenaje sostenible (SUDS). Bogotá, Colombia: Universidad de Los Andes. 